\title{
Extinct and living mammals of the island of Marettimo (Ae- gadian archipelago, Trapani), off the north-western Sicilian coast (Italy): a review of evidence and historical data
}

\author{
Marco Masseti' \& Bruno Zava ${ }^{2,3}$ \\ ${ }^{1}$ IUCN Deer Specialist Group; e-mail: marcomasseti55@gmail.com \\ ${ }^{2}$ Museo Civico di Storia Naturale di Comiso (Ragusa), Italy \\ ${ }^{3}$ Wilderness-Studi ambientali, Palermo; e-mail: wildernessbz@hotmail.com
}

\begin{abstract}
Marettimo island is the furthest of the Aegadian archipelago from the coast of north-western Sicily. Nevertheless, the presence of continental and non-endemic mammals on the island has been documented since the Mesolithic period. Over the course of historical times the introduction of mammals on the small island has continued without any apparent solution of continuity, even attempting to involve neo-Arctic species such as the Eastern cottontail. Recently, evidence has been found of the monk seal visiting some of the island's caves.
\end{abstract}

KEY WORDS Anthropocorus mammals, island ungulates, monk seal, Eastern cottontail.

Received 26.07.2021; accepted 28.10.2020; published online 22.11.2021

\section{INTRODUCTION}

Located off the northwestern coast of Sicily (Italy), the Aegadian archipelago consists of the three main islands of Favignana, Levanzo and Marettimo (Fig. 1). The latter $\left(37^{\circ} 55^{\prime} \mathrm{N}, 12^{\circ} 04^{\prime} \mathrm{E}\right.$, 12 sq. $\mathrm{km}$ ) is the furthest from Sicily, which is about $30 \mathrm{~km}$ away. Marettimo has separated from the mainland several millennia before the other two islands of the archipelago. The result is that there are some endemic plants, such as the Brassica macrocarpa Guss., and the fennel Seseli bocconi Guss., a shrub that grows on the cliffs around the Semaforo (cf. Pignatti, 1982). Along the coastal belt, typical plants of the Mediterranean garrigue vegetate, such as Helichrysum pendulum C. Prest, Rosmarinus officinalis Schleid., Euphorbia dendroides L., and Euphorbia bivonae Steud. At higher altitudes, Erica multiflora L., Cistus incanus L., Ruta chalepensis L., Daphne oleifolia Lam., Quercus ilex L., Pinus halepensis Mill., Lonicera implexa Aiton, Buplerum sp., Scabiosa sp., and Dianthus sp. thrive as for example around the highest peak of the island which culminates at $686 \mathrm{~m}$ above sea level, on Monte Falcone (Francini \& Messeri, 1956) (Fig. 2).

In various times of the year, Marettimo is visited by numerous migratory ornithic species (Massa, 1973; Agostini et al., 2000; Massa et al., 2015), including herons and woodcocks, Scolopax rusticola L., 1758, while the resident species comprise wild pigeons, Columba livia Gmelin, 1789, ravens, Corvus corax L., 1758, Bonelli's eagles (Vieillot, 1822), peregrine falcons, Falco peregrinus Tunstall, 1771, yellow-legged gulls, Larus michahellis michahellis Naumann, 1840, and barn owls, Tyto alba (Scopoli, 1769). The island is also one of the few Italian territories to host a colony of the rare storm petrel, Hydrobates pelagicus (Linnaeus, 1758) (Brichetti \& Fracasso, 2003), and of the Eleonora's falcon, Falco eleonorae Géné, 1834 
(Premuda \& Mellone, 2008). In medieval times, the circum-Sicilian islands were considered an important natural reservoir for the gathering of birds of prey for hunting activities (Bresc, 1980). Among them, the rocky solitudes of Marettimo represented one of the most interesting places for collecting falcons (Masseti, 2016).

\section{MAMMALS OF THE PAST}

In Late Pleistocene-Early Holocene times, the Aegadian Islands were populated by a very interesting mammalian fauna, including many continental species, as is also documented by the numerous artistic testimonies of the Grotta del Genovese on Levanzo (Graziosi, 1962; Masseti \& Rustioni, 1990). Osteological remains of the common fox, Vulpes vulpes (L., 1758), the European onager, Equus hydruntinus Regalia, 1907, the wild boar, Sus scrofa L., 1758, the red deer, Cervus elaphus L., 1758, and the wild ox, Bos primigenius Bojanus, 1827, have been recorded from Favignana and Levanzo (Malatesta, 1957; Mannino et al., 2012; Graziosi, 1950, 1973; Cassoli \& Tagliacozzo, 1982; Mannino \& Thomas, 2010; Tusa et al., 2013), while the occurrence of the European water vole, Arvicola amphibious L., 1758, has been reported only from the latter island (Cassoli \& Tagliacozzo, 1982). On Marettimo, the recent archeological exploration of the fossiliferous sand of Grotta del Tuono has pro-

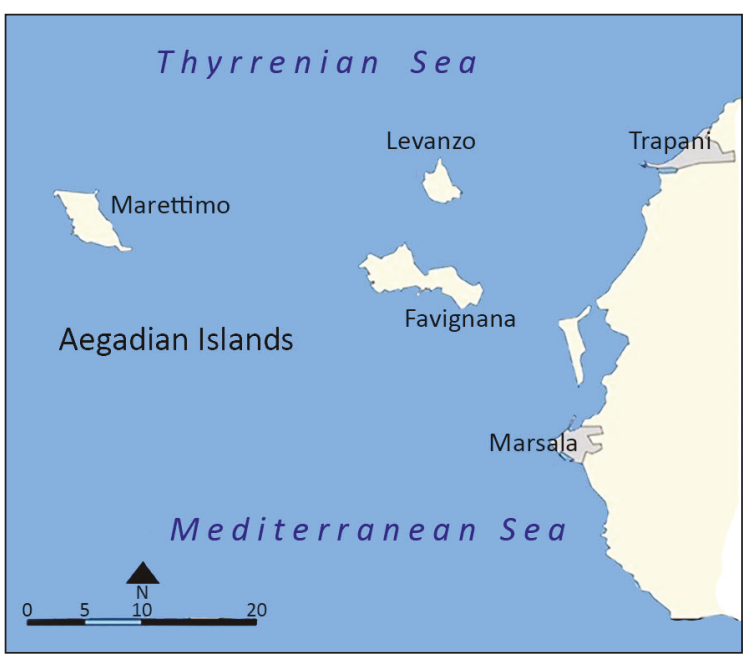

Figure 1. Map showing the location of the Aegadian Islands in western Sicily. vided remains of rayed Mediterranean limpets, Patella caerulea (L., 1758), and red deer (Antonioli et al., 2016a) (Fig. 3). Carbon 14 testing of these finds has resulted in the dating of 11, 617 +/-150 BP (Lo Presti et al., 2019), frankly placing them in Mesolithic or at least Pre-Neolithic times. According to Antonioli et al. (2016a), this would imply an important and novel interpretation for the history of seafaring that for the Mediterranean Sea seems to have started with the Neolithic (Mannino, 2015).

The dating of the Marettimo deer teeth would suggest that the large-sized mammals of the most distant of the Aegadian Islands was still present in fairly recent times (see also Antonioli et al., 2016b). Archaeological evidence suggests that these late Mesolithic deer may not have reached Marettimo by swimming, but may have been brought there by humans.

The Late Pleistocene-Early Holocene fauna was destined to disappear in the following epochs even if still in the $12^{\text {th }}$ century AD, Idrisi, the famous Arab geographer at the court of Roger II, described Marettimo as without ports but rich in ungulates: "... to the west of the island is Marettimo, situated opposite Tunis and Carthage and thirty miles from Favignana; it lacks ports and its fauna includes goats and gazelles" (cf. Amari \& Schapparelli, 1883; Rizzitano, 1994). The latter ungulates may have been introduced for hunting purposes. In fact, it has been an established technique since antiquity to release big game on remote islands in order to provide an always available supply of meat along the maritime routes. Afterwards, it seems that the reputation of Marettimo remained almost unchanged for some centuries since, in the first half of the $14^{\text {th }}$ century, another Muslim geographer, Sahab Ad Din Abu al-Abbas Ahmad Ibn Yahya al-Umari, probably taking up what was already indicated by Idrisi, still reported in his Masâlik 'al 'Absâr that on Gazirat Malitima, (= "island of Marettimo") "There are some antelopes and wild goats" (cf. Ruta, 2007). Unfortunately, it is not known whether these last ungulates described by the Arab scholars were really gazelles, which species of them, or some other type of bovid, but as a whole, it seems that the Aegadian archipelago has shown since ancient times its vocation as a territory to be reserved for game breeding (Masseti, 2016). Even in not so remote times, in its perfumed scrub, other large fauna must be experienced, such as the ciervos y puercos (= "deer and 


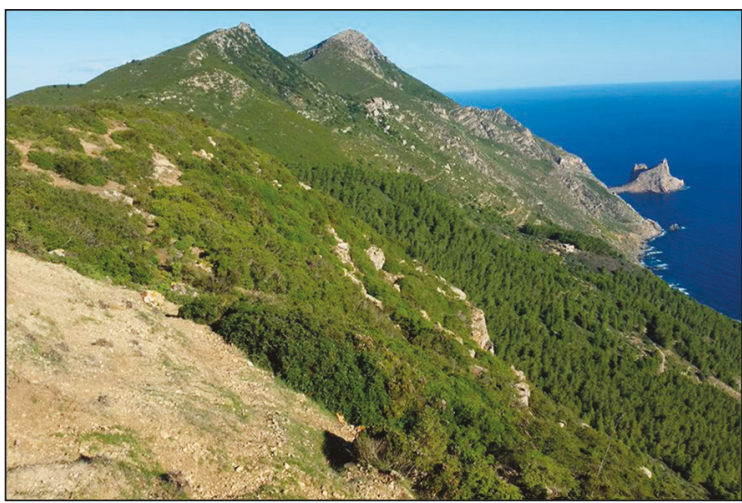

Figure 2. View of the island of Marettimo (Aegadian Islands) from Pizzo Semaforo towards Punta Troia (photo by Vito Vaccaro).

pigs") that in 1513 were decimated by the Spanish crews of Pietro Navarro's ships after they landed at Favignana (Di Marzo, 1858; Aricò, 1992; Maurici 1999; Bresc, 2010). Deer would thus have disappeared from the Aegadian Islands, in ancient times "... as evidenced by the graffiti and bones of the Grotta del Genovese, but also by a toponym such as Portella del Cervo, on the Montagna Grossa of Favignana" (Malaguzzi, 1989; cf. Riggio, 1976). Moreover, literary sources report the occurrence of herds of deer and rabbits on Favignana, from at least as far back as the beginning of the $18^{\text {th }}$ century (Massa, 1709), while Amico (1757-1759) said that the island abounded in "deer and rabbits". In particular, Dùran (1928) stated without hesitation that the ancient fauna of Marettimo had long since disappeared, as had "...the large African mammals, the boars imported by the Bourbons, and the deer of Philip IV" (cf. Masseti, 2016). Together with the toponyms relating to the deer of Favignana and Marettimo, La Mantia \& Cannella (2008) are however of the opinion that the references by Amico (1757-1759) and Dùran (1928) appear to be inconclusive.

\section{Wild goats}

Still according to Ibn Yahya al-Umari, another satellite island of Sicily, which unfortunately remains unnamed, must have had a population of wild goats. The already mentioned Idrisi had reported the presence of these ungulates even from the island of Vulcano, in the Aeolian archipelago, specifying at the same time that the even more distant Pantelleria was abundant: "... of goats that have passed from

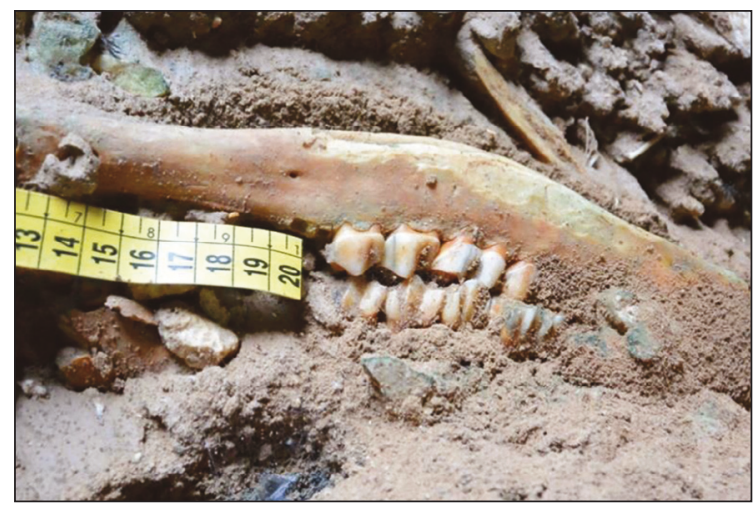

Figure 3. Osteological remains and teeth of red deer, Cervus elaphus from Grotta del Tuono, Marettimo (from Antonioli et al., 2016a).

the domestic to the wild state" (Rizzitano, 1994; cf. Amari \& Schapparelli, 1883). Populations of wild goats, Capra aegagrus Erxleben, 1777, have been present on the Mediterranean islands since time immemorial (Masseti, 2009, 2016). Referring to the past spread of these ungulates on Favignana, the Sicilian scholar Vito Amico (1757-1759) observed that: “... in niun modo però combina col vero che sia stata la Capraria mentovata da Omero, famosa per le fiabe del gigante Polifemo e di Ulisse, come afferma Cluverio" [... in no way, however, is it true that it was the Capraria mentioned by Homer, famous for the fables of the giant Polyphemus and Ulysses, as Cluverius states]". Since ancient times, the archipelago has also been called by the names of Aegates, Aigatai, Aegades, Egadi because of the "... goats, which then as now abounded, called by Pliny capraria" (cf. Amico, 1757-1759). All the names, like that of Egusa mentioned by Pliny the Elder (Naturalis historia, III: 92), recall the ancient Greek term aix (= "goat"), which is very common in island toponyms, both in its Greek and Latin (capra) forms (Barchiesi et al., 1982). In and around the Channel of Sicily, populations of wild goats survived on Lampedusa until about the middle of the $19^{\text {th }}$ century and on the Tunisian island of La Galite until 1904, when they became extinct due to persecution by workers during the construction of the lighthouse on the nearby islet of Galitone (Lauvanden, 1924; Masseti \& Zava, 2002; Masseti, 2009a, 2014) (Fig. 4). It is therefore no coincidence that the Arabs called La Galite as Djebel Mazzat or "mountain of goats" (Galbert, 1904). 


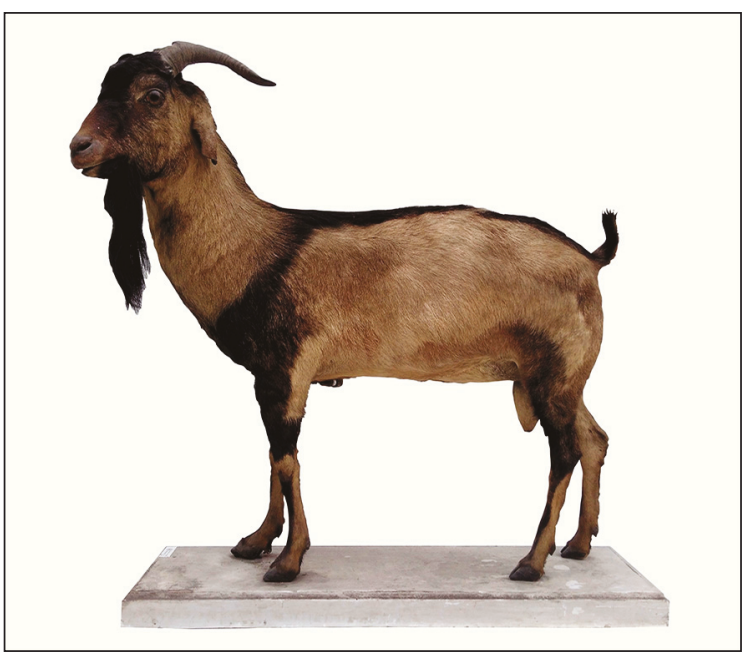

Figure 4. Stuffed specimen of subadult male goat, possibly obtained from the Tunisian island La Galite (photo by Gianni Insacco; courtesy Museo Civico di Storia Naturale, Comiso, Ragusa).

\section{EXTANT MAMMALS OF MARETTIMO}

In line with the wealth of wildlife in the past, even today Marettimo reveals an interesting presence of mammals within its territory. In general, these are zoological species of anthropochorous origin, introduced to the island for the most different purposes, including hunting and aesthetic reasons. Among these, some unintentional introductions cannot be excluded either, as in the case of some of man's most common commensal micromammals.

The terrestrial mammalian species currently reported for Marettimo are 10. They include three rodents (murids), three artiodactyls (one suid, one cervid and one bovid), one lagomorph (leporid), one representative of the Soricidae family, and at least two bats.

\section{Aegadian shrew, Crocidura sicula aegaten- sis Hutterer, 1991}

Krapp (1969) reported for the first time a taxonomic representative of the genus Crocidura (Wagler, 1832), from the Aegadian archipelago, that he referred to C. suaveolens (Pallas, 1811). However, this shrew was later recognised as belonging to the species Crocidura sicula Miller, 1900, the Sicilian shrew (Figure 5). In fact, from a cytogenetic analysis of soricids found on Sicily and the island of Gozo (Maltese archipelago), it became evident that all the members of the Crocidura genus from the Siculo-Maltese archipelago actually belong to the same species $C$. sicula (Vogel et al., 1989, 1990; Sarà et al., 1990; Sarà \& Vitturi, 1996; Lo Brutto et al., 2004). This taxon is endemic to Sicily, the Aegadian archipelago, Ustica, the already mentioned Gozo, and is considered as being extinct on Malta (Vogel et al., 1990; Sarà, 1995, 1996; Masseti, 2002; 2008). It is a probable survivor from the Pleistocene, but not related to the endemic $C$. esuae Kotsakis, 1986, living in the Middle Pleistocene of Sicily (Kotsakis 1986; Hutterer 1990; Sarà, 1995), and apparently replaced by $C$. sicula since the terminal Pleistocene (Bonfiglio et al., 1997). The Sicilian shrew has also been identified as a conspecific form of C. canariensis (Hutterer et al., 1987), endemic to the Canary islands (Sarà, 1995). According to certain authors (Vogel et al., 1990, Sarà, 1995, 1996, and 1998; Masseti, 2002 and 2008), C. sicula is to be comprised among the extinctions that took place also on the small island of Lampedusa in the Sicilian channel in the course of the Holocene. Hutterer (1991) found some morphological peculiarities in the Aegadian population so as to justify its inclusion in the new subspecies $C$. sicula aegatensis Hutterer, 1991. Previously, however, Krapp (1969) already expressed the view that sub-specific determination could not be made, but maybe the island of Marettimo had his own local race. More recently the occurrence of $C$. sicula aegatensis has been also reported from the Maltese island of Comino (Aloise et al., 2011).

Together with the Sicilian shrew very few other micromammals are now considered endemic to the Mediterranean islands. These are essentially represented by another species of Soricid, the Cretan white-toothed shrew, C. zimmermanni Wettstein, 1953, and two rodents, the recently discovered Cypriot mouse, M. cypriacus, and perhaps the Kerkennah islands dipodil, Dipodillus zakariai Cockrum, Vaughan \& Vaughan, 1976, from the namesake Tunisian archipelago (Masseti, 2009b). These are the only mammals left from a completely vanished Pleistocene faunal world.

\section{Bats}

Until now, bats have been scarcely reported from the Aegadian Islands. Only the occurrence of 
three species is known for the archipelago. In Favignana Krampitz (1957) described the presence of the Kuhk's pipistrelle, Pipistrellus kuhli Kuhl, 1817, that was later confirmed by Fiore et al. (1992) and Fornasari et al. (1997), while the present study recorded for the first time the greater horseshoe bat, Rhinolophus ferrumequinum (Schreber, 1774), $P$. kuhli and the free-tailed bat, Tadarida teniotis (Rafinesque, 1814), from Levanzo. In the course of the present study, P. kuhli and T. teniotis have been also observed for the first time on Marettimo, representing for the moment, the only bats so far recorded on this small Aegadian island.

\section{Lagomorphs}

The rabbit, Oryctolagus cuniculus (L., 1758), is the only leporid currently present on Marettimo (Massa, 1973; Flux \& Fullagar, 1992; Vaccaro, 2016). Ist occurrence on the island is also documented by one specimen in the collections of the $\mathrm{Mu}-$ seum of Zoology La Specola of the University of Florence (MZUF n. coll. 13170, 5.IV.1990).

Of the hares, Lepus sp., mentioned by Smyth (1824) there seems to be no more documentation.

\section{Carnivores}

A few authors, such as Pratesi \& Tassi (1974), Racheli (1986) e Malaguzzi (1989), did not exclude the survival of feral cats, Felis silvestris Schreber, 1777, on Marettimo. The same information was also quoted by Masseti (2010).

\section{Artiodactyls}

As we have seen, the presence of ungulates on Marettimo is particularly abundant. It comprises at least three species, such as Sus scrofa L., 1758, the red deer, Cervus elaphus L., 1758, and the Asiatic mouflon, Ovis orientalis Gmelin, 1774.

The island seems to be populated by a kind of wild pig, introduced who knows how long ago (Dùran, 1928; Racheli, 1986; Sara, 1998; Sironi, 2004): “... which the islanders call wild boars' but which 'are nothing more than pigs that have 'chosen freedom" (Malaguzzi, 1989). Their presence has been reported at least since 1910 (Dùran, 1910), but according to Sarà $(1998,2008)$ some wild boar launches were also carried out in the second half of the $20^{\text {th }}$ century, and more precisely in the $1980 \mathrm{~s}$, by private citizens for hunting purposes (Masseti, 2016a). According to Vaccaro (2016), real wild boars (from Maremma) would have been imported to Marettimo at the same time as mouflons were introduced, i.e. around the mid-1970s. The wild boars will certainly have interbred with wild pigs and at this stage it will be difficult to make meaningful taxonomic distinctions. Having caused a great deal of damage to the island's dense maquis, these suids seem to have become very rare, partly because of the local water shortage (Sironi, 2004).

In 1976, six Tyrrhenian mouflons, Ovis orientalis musimon (Pallas, 1811), from a Tuscan farm, were also introduced to Marettimo (Sacchi et al., 1994) (Fig. 6). In the spring of 1992, although their average growth rate was rather low, they had already

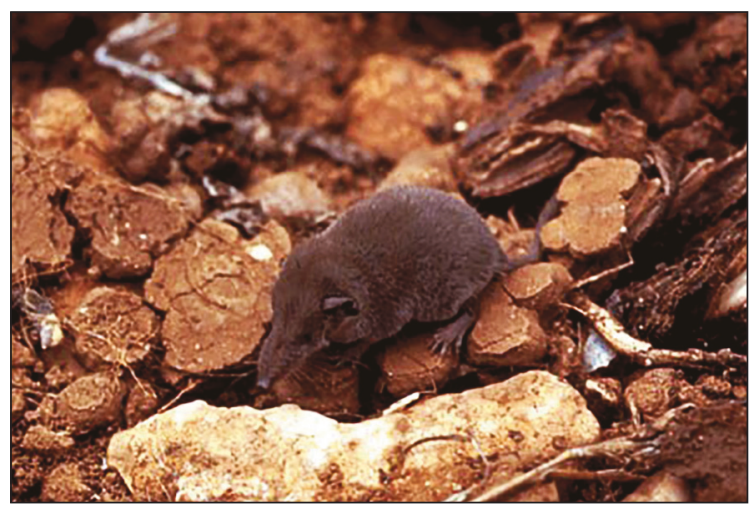

Figure 5. Aegadian shrew, Crocidura sicula aegatensis Hutterer, 1991 (photo by Paolo Agnelli).

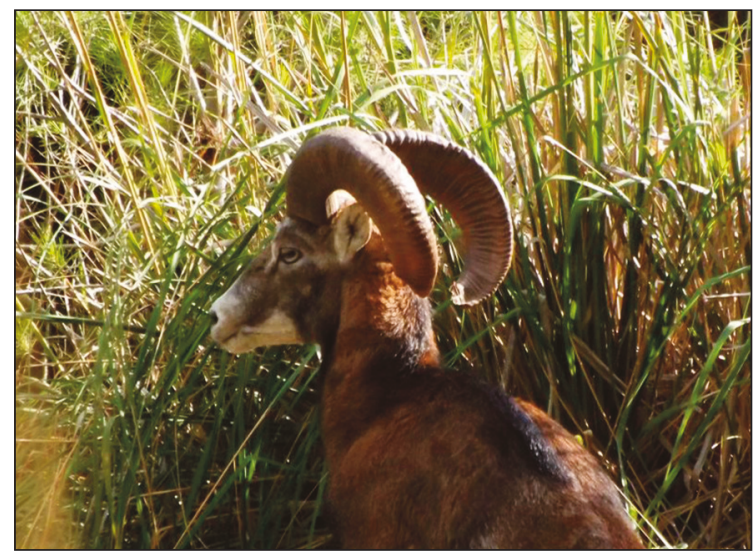

Figure 6. Tyrrhenian mouflons, Ovis orientalis musimon (Pallas, 1811), from a Tuscan farm, were introduced onto Marettimo in 1976 (photo by Vito Vaccaro). 
reached 51 individuals (Sacchi et al., 1994; Masseti, 2016a). The habitat study carried out by Sacchi et al. (1994) showed a use by these ungulates of all the different environmental types in proportion to their availability, while it seems that only the vegetation of the pulvinus shrub community, such as Helichrysum rupestre (Rafin.) DC. var. messerii Pignatti, Senecio cineraria DC., and Polycarpon alsinifolium (Biv.) DC.),, is avoided. The current estimate of the entire mouflon population on Marettimo could be around one hundred individuals (Vaccaro, 2016).

Some red deer escaped from an enclosure of the Marettimo Residence some twenty-five years ago and today eight or so individuals of the species are presumed to inhabit the island. The architecture of the antlers of some of them, such as the male over five years old shown in Fig. 7, is well structured, with the occurrence of both the brow and the bey (or bez) tines, but fairly simplified possibly due to the limited trophic resources available on the island.

\section{Rodents}

The island is characterised by the presence of the wild mouse subspecies Apodemus sylvaticus dichrurus (Rafinesque-Schmaltz, 1814) (Krapp, 1969; Amori, 1993; Sarà \& Casamento, 1995; Amori \& Masseti, 1996). This subspecies is considered to be native to Mediterranean Europe, and is therefore present not only in central and southern Italy, Sicily, Sardinia and Corsica, but also in Spain, southern France and much of the Balkan Peninsula (Capizzi \& Filippucci, 2008).

The most common commensal murids, such as the black rat, Rattus rattus (L., 1758), and the house mouse, Mus domesticus Rutty, 1801, are also common there (Krapp, 1969; Amori, 1993; Amori \& Masseti, 1996).

Eastern cottontail, Sylvilagus floridanus (J. A. Allen, 1890)

In relatively recent times, an attempt to introduce the Eastern cottontail, Sylvilagus floridanus (J.A. Allen, 1890) (Zava, 1992; Masseti, 2008; Angelici \& Spagnesi, 2008; Masseti \& De Marinis, 2008) was carried out on the island (Fig. 8). This is a small American leporid, whose primary distribution covers a vast area from southern Canada to north-western South America (Chapman \& Ceballos, 1990).
Eastern cottontails have been widely transplanted beyond the territories of their natural distribution in North America and Europe. In the Old World, the species has been introduced to France, where it is now extinct, and as well as to Italy (Lapini, 1999). In Italy, the earliest evidence of its occurrence dates back to 1966 (Doria, 1991; Spagnesi 2002 and 2008; Andreotti et al., 2001), and populations of cottontail are today dispersed in Piedmont, Friuli-Venezia Giulia and Tuscany (Lever, 1985; Lapini, 1999; Spagnesi, 2002; Masseti, 2003; Angelici \& Spagnesi, 2008). The only known attempt for the introduction of the species onto Mediterranean islands seems to have been performed on Marettimo during the 1980 s, but there is no evidence that these animals originated any local population (Masseti \& De Marinis, 2008; cf. Zava, 1992). In fact, the result of this attempted release - which was even illegal - did not give rise to stable populations over time and independent from subsequent launches.

\section{Monk seal, Monachus monachus (Hermann, 1779)}

This species deserves a separate discussion, as it cannot be considered exclusively a marine mammal because it depends on terrestrial haul-out areas (typically found in marine caves) for giving birth and lactating its young. Over the period between 1998 and 2010, sightings have been reported in a somewhat repetitive manner in the Aegadian archipelago in particular in the years 2001, 2002, 2004, 2006 , and 2010 . The majority of sightings were reported in coastal areas of the island of Marettimo (Mo, 2011). About fifteen years ago, a squid fisherman spotted an individual between Cala Fredda and Cala Dogana (Levanzo) for a whole week (riferimento). According to Mo (2011), the repeated observations of seals over the years in wide geographic areas characterised by multiple sightings would suggest that the seals are not observed incidentally and that there may be a regular use of selected stretches of coast over time. Recent cave in-situ monitoring carried out by ISPRA (Istituto Superiore per la Protezione e la Ricerca Ambientale) in collaboration with the Marine Protecte Area of the Aegadian islands has shown that seals have used a few caves of the island of Marettimo and Favignana as resting sites for several years from 2011 onwards (Giulia Mo 2021, pers. comm.). 


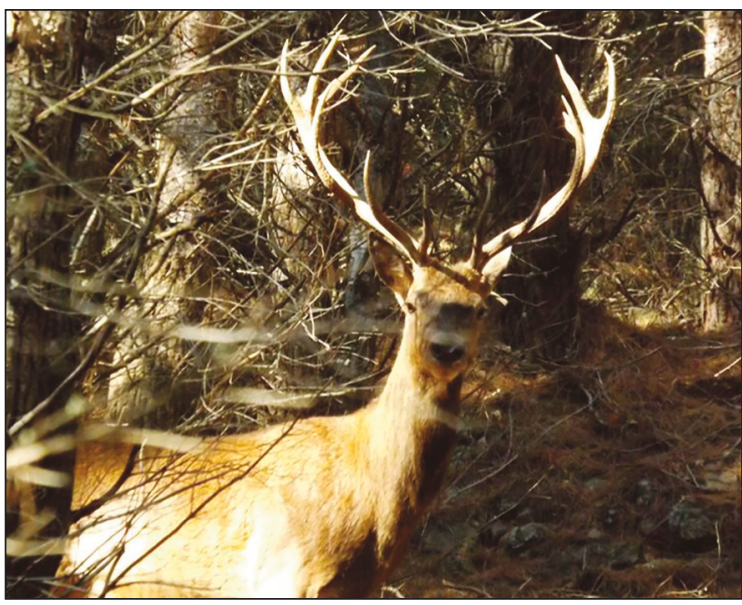

Figure 7. A few red deer, Cervus elaphus L., 1758, escaped from an enclosure of the Marettimo Residence some 25 years ago and today eight or so individuals of the species are presumed to roam free on the island (photo by Vito Vaccaro).

\section{CONCLUSIONS}

Since the late Pleistocene, the sequence of the mammalian fauna of the Aegadian archipelago is congruent with that of neighbouring Sicily, being exclusively characterised by continental elements. As in most of Sicily, this fauna would have been destined for extinction on the smaller islands, only to be replaced by anthropochorous species, introduced for various purposes, including food, hunting and perhaps even aesthetics. The extant occurrence of non-volant continental mammals on Marettimo is essentially linked to the introduction by man during the most recent Holocene.

It cannot be excluded that, in the past, deer, goats, hares and rabbits could have been released in a free-ranging state, while man exerted a control on the number of the animals through justified hunting, as occasion demanded. This could have been one way of simplifying management problems, considering Marettimo as a natural enclosure and allowing the phytophagous herds to derive their food supply directly from the carrying capacity of the environment. One cannot overestimate the importance of islands inhabited by free-ranging populations of herbivores, which represented living depositories of animal proteins available at any time along the marine routes of the Mediterranean Sea. Indeed, some of the herbivores most adaptable to peculiar environmental conditions, even of small islands,

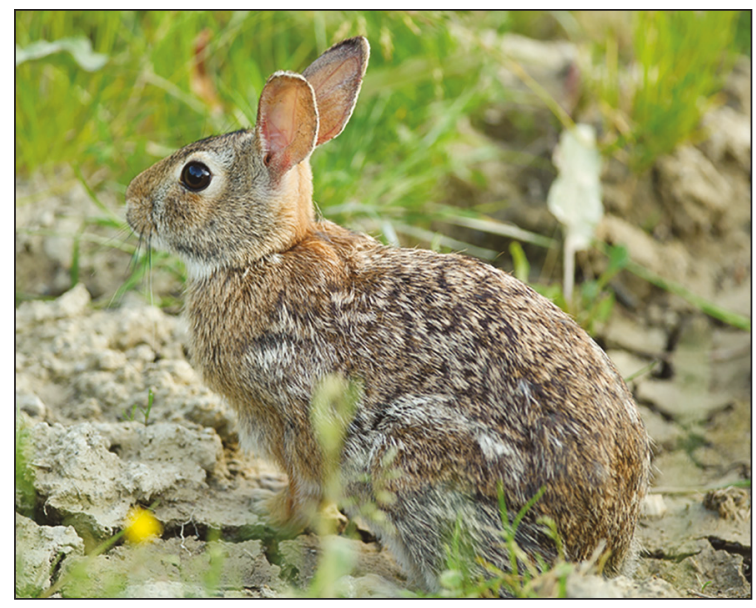

Figure 8. Eastern cottontail, Sylvilagus floridanus (J.A. Allen, 1890), a small American leporid introduced in Marettimo but with no evidence of current populations (photo by Fabrizio Darmanin).

were brought by sailors and let loose on islands so that they could breed and provide a store of fresh meat that would be readily available for the passengers of ships (Masseti, 1998). Beyond this peculiar use as natural reservoirs of fresh meat, the European nobility often regarded many of the islands that would otherwise be unproductive, especially those located near the mainland coasts, simply as game preserves (Masseti \& Zava, 2002).

\section{ACKNOWLEDGEMENTS}

In the course of this study we have been fortunate to have the help of many friends and colleagues. We are particularly grateful to Tommaso Caruso, Levanzotrekk (Levanzo, Trapani); Gianni Insacco, Museo Civico di Storia Naturale, Comiso (Ragusa); Giuseppe Pisciotta Atmosphereblum (Levanzo, Trapani), and Luca Sineo, Facoltà di Scienze MFN dell'Università di Palermo. Special thanks are due to Giulia Mo, Istituto Superiore per la Protezione e la Ricerca Ambientale (ISPRA), Rome, for her precious information on the occurrence of the monk seal in the Aegadian archipelago, and to Viro Vaccaro, Associazione Culturale, Sportiva, Ricreativa, Turistica "Marettimo" (Marettimo, Trapani), for providing us with data and photographs on the current presence of mammals on Marettimo. 


\section{REFERENCES}

Agostini N., Logozzo D. \& Panuccio M., 2000. The island of Marettimo (Italy), important bird area for the autumn migration of raptors. Avocetta, 24: 95-99.

Aloise G., Baldacchino A.E. \& Amori G., 2011. Crocidura sicula Miller, 1900 (Mammalia, Soricidae): a possible new record from Comino island (Maltese Islands). Biodiversity Journal, 2: 145-148.

Amari M. \& Schapparelli C., 1883. L'Italia nel "Libro di Ruggero". Compilato da Edrisi. Memoria letta nella seduta del 17 dicembre 1876. Col. Tipografia Salviucci, Roma.

Amico V.M., 1757-1759. Lexicon topographicum Siculum. In quo Siciliae, Urbes, Opida, cum diruta, tum extantia, Montes, Flumina, Portus, adjacentes Insulae, ac singula Loca describuntur, illustrantur. Catania; traduzione di G. Di Marzo. Palermo, 1855-1856. Rist. anastatica Forni, Bologna.

Amori G., 1993. Italian insectivores and rodents: extinctions and current status. Supplemento alle ricerche di biologia della selvaggina, 21: 115-134.

Amori G. \& Masseti M., 1996. Does the occurrence of predators on Central Mediterranean islands affect the body size of micromammals? Vie Milieu, 46: 205 211.

Andreotti A., Baccetti N., Perfetti A., Besa M., Genovesi P. \& Guberti V., 2001. Mammiferi ed Uccelli esotici in Italia: analisi del fenomeno, impatto sulla biodiversità e linee guida gestionali. Quaderni di Conservazione della Natura, 2, Mininestro dell'Ambiente, Istituto Nazionale per la Fauna Selvatica, Ozzano dell'Emilia (Bologna).

Angelici F.M. \& Spagnesi M., 2008. Sylvilagus floridanus (J.A. Allen, 1890). In: Amori G., Contoli L. \& Nappi A. (Eds), Fauna d'Italia. Mammalia II. Erinaceomorpha, Soricomorpha, Lagomorpha, Rodentia. vol. XLIV: 33-65. Edizioni Calderini de il Sole24 Ore, Milano: 303-311.

Antonioli F., Merizzi J., Tusa S., Lo Presti V., Quarta G. \& Calcagnile L., 2016a. The Grotta del Tuono (Marettimo Island) fossil deposit and new hypotesis of navigation. Abstracts of oral and poster presentations “GeoSUB - Underwater geology", Ustica, 1317 September 2016: 17.

Antonioli F., Lo Presti V., Morticelli M., Bonfiglio L., Mannino M., Palombo M.R., Sannino G.M., Ferranti L., Furlani S., Lambeck K., Canese S., Catalano R., Chiocci F., Mangano G., Scicchitano G. \& Tonielli S., 2016b. Timing of the emergence of the EuropeSicily bridge (40-17 cal. ka BP) and its implications for the spread of modern humans 2016. In: Geological Society. vol. 411 Submerged Landscapes of the Continental Shelf Special Publications series, London. https://doi.org/10.1144/SP411.1.
Aricò N. (Ed.), 1992. Negro F. \& Ventimiglia C.M. Atlante di città e fortezze del Regno di Sicilia. Sicania, Messina.

Barchiesi A., Centi A., Corsaro M., Marcone A. \& Ranucci G., 1982. Gaio Plinio Secondo. Storia naturale. I. Cosmologia e geografia. Libri 1-6.

Bonfiglio L., Insacco G., Marra A.C. \& Masini F., 1997. Large and small mammals, amphibians and reptiles from a new late Pleistocene fissure filling deposit of the Hyblean Plateau (South Eastern Sicily). Bollettino della Società Paleontologica Italiana, 36: 92122.

Bresc H., 1980. La chasse en Sicilie (XIIe-XVe siecles). In: Actes du Colloque du Centre d'Êtudes Mèdiévales de Nice La chasse au Moyen Age. Nice, 22th-24th June 1979. Publ. Fac. Lettres Sc. Hum. Nice ; Les Belles Lettres, Paris: 201-217.

Bresc H., 2010. Una stagione in Sicilia. Edizioni Marcello Pacifico, Palermo.

Brichetti P. \& Fracasso G., 2003. Ornitologia italiana. Volume I, Gavidae-Falconidae. Alberto Perdisa Editore, Bologna.

Capizzi D. \& Filippucci M.G., 2008. Apodemus sylvaticus (Linnaeus, 1758). In: Amori G., Contoli L. \& Nappi A. (Eds.), Fauna d'Italia. Mammalia II. Erinaceomorpha, Soricomorpha, Lagomorfa, Rodentia. Vol. XLIV. Edizioni Calderini de Il Sole 24 ORE, Milano: 604-616.

Cassoli P.F. \& Tagliacozzo A., 1982. La grotta di Cala Genovesi a Levanzo. Rivista di Scienze Preistoriche, 37: 124-133.

Chapman J.A. \& Ceballos G., 1990. The cottontains. In: Chapman J.A. \& Flux J.E.C. (Eds.), Rabbits, hares and pikas. Status Survey and Conservation Action Plan. IUCN/SSC Lagomorph Specialist Group. International Union for Conservation of Nature and Natural Resources (IUCN), Gland (Switzerland): 95-110.

Di Marzo-Ferro G., 1858. Guida Istruttiva per Palermo e suoi dintorni riprodotta su quella del Cav. D. Gaspare Palermo dal Beneficiale Girolamo Di MarzoFerro. R. Livio Portinaio editore-libraio, Palermo.

Doria G., 1991. Silvilago o minilepre Sylvilagus floridanus (Allen). In: Capocaccia Orsini L. \& Doria G. (Eds.), Animali e piante dalle Americhe all'Europa. Sagep Editrice, Genova: 68.

Duran V., 1910. Corrispondenza da Marettimo. Giornale Di Trapani, 11 marzo 1910: 6.

Duran P.E., 1928. Una perla in fondo al Mare. Sintesi storica-politica-sociale dell'Isola di Marettimo (Egadi, Trapani). Ristampato dal figlio Vincenzo Duran, Roma.

Fiore M., Violani C. \& Zava B., 1992. Chirotteri delle Isole circumsiciliane. I - Vulcano (Eolie). Atti della Società Italiana di Scienze Naturali e del Museo Civico di Storia Naturale di Milano, 132: 169-180. 
Flux J.E.C. \& Fullagar P.J., 1992. World distribution of the rabbit Oryctolagus cuniculus on islands. Mammal Review, 22: 151-205.

Fornasari L., Violani C. \& Zava B., 1997. I chirotteri italiani. L'Epos, Palermo, 130 pp.

Francini E. \& Messeri A., 1956. L'isola di Marettimo nell'Arcipelago delle Egadi e la sua vegetazione. Webbia, 11 (1955): 607-846.

Galbert D.J.M.M., 1904. L'Île de la Galite, notes de voyage. Imprimerie de Allier fréres, Grenoble.

Graziosi P., 1950. Le pitture e i graffiti preistorici dell'isola di Levanzo nell'arcipelago delle Egadi, Sicilia. Rivista di Scienze Preistoriche, 5: 1-43.

Graziosi P., 1962. Levanzo. Pitture e incisioni. Sansoni, Firenze.

Graziosi P., 1973. Levanzo. Pitture e incisioni. Edizioni Sansoni, Firenze.

Hutterer R., 1990. Temporal and geographic variations of shrews pf the Sicilian-Maltese archipelago since the Pleistocene. Vie et Milieu, 2-3: 213-217.

Hutterer R., 1991. Variation and evolution of the Sicilian shrew: taxonomic conclusions and description of a possibly related species from the Pleistocene of Morocco (Mammalia: Soricidae). Bonner zoologische Beiträge, 42: 241-251.

Kotsakis T., 1986. Crocidura esui n. sp. (Soricidae, Insectivora) du Pléistocène de Spinagallo (Sicilie orientale, Italie). Geologica Romana, 23: 51-64.

Krampitz H.E., 1957. Ricerche sugli emoparassiti dei micromammiferi selvatici della Sicilia. Rivista di $\mathrm{Pa}$ rassitologia, 36: 369-414.

Krapp F., 1969. Terrestrische Kleinsäugetiere von den ägadischen Inseln (Mammalia: Insectivora, Rodentia) (Provinz Trapani, Sizilien). Memorie del Museo civico di Storia naturale di Verona, 17: 331-347.

La Mantia T. \& Cannella Z., 2008. Presenza storica dei grossi Mammiferi in Sicilia. In Massa B. (ed.): Atlante della Biodiversità della Sicilia: Vertebrati terrestri. Studi e Ricerche, 6. Arpa Sicilia, Palemo: 87106.

Lapini L., 1999. Sylvilagus floridanus (J.A. Allen, 1890). In: Mitchell-Jones et al. (a cura di), The atlas of the European mammals. Academic Press, Londra: 174175.

Lavauden L., 1924. La chasse et la faune cynègètique en Tunisie. Imprimerie Guènard \& Franchi, Tunisi.

Lever C., 1985. Naturalized mammals of the world. Longman, New York.

Lo Brutto S., Arculeo M. \& Sarà M., 2004. Mitochondrial simple sequence repeats and 12S-rRNA gene reveal two distinct lineage of Crocidura russula (Mammalia, Soricidae). Heredity, 92: 527-533. https://doi.org/10.1038/sj.hdy.6800448

Lo Presti V., Antonioli F., Palombo M.R., Agnesi V., Biolchi S., Calcagnile L., Di Patti C., Donati S., Fur- lani S., Merizzi J., Pepe F., Quarta G., Renda P., Sulli A. \& Tusa S., 2019. Palaeogeographical evolution of the Egadi Islands (western Sicily, Italy). Implications for late Pleistocene and early Holocene sea crossings by humans and other mammals in the western Mediterranean. Earth-Science Reviews, 194: 160181. https://doi.org/10.1016/j.earscirev.2019.04.027

Malaguzzi G., 1989. Galapagos, Altamira e molto altro... Oasis, 7/8: 78-93.

Malatesta A., 1957. Terreni, faune e industrie quaternarie dell'Arcipelago delle Egadi. Quaternaria, 4: 165190.

Mannino M.A., 2015. The question of voyaging by foragers who lived in the central Mediterranean. Eurasian Prehistory, 11: 165-184.

Mannino M.A. \& Thomas K.D., 2002. Studio archeozoologico dei reperti faunistici dalla Grotta d'Oriente a Favignana (Trapani). Quaderni del Museo Archeologico Regionale “Antonino Salinas”, 8: 23-54.

Mannino M.A. Catalano G., Talamo S., Mannino G., Di Salvo R., Schimmenti V., Lalueza-Fox C., Messina A., Petruso D., Caramelli D., Richards M.P. \& Sineo L., 2012. Origin and diet of the prehistoric hunter-gatherers on the Mediterranean island of Favignana (Ègadi Islands, Sicily). PLoS ONE, 7 (11): e49802. https://doi.org/10.1371/journal.pone.0049802

Massa G.A., 1709. La Sicilia in prospettiva. Parte seconda. Stamperia di Francesco Cichè, Palermo.

Massa B., 1973. L'avifauna estiva degli arcipelaghi delle Egadi e dello Stagnone. Atti dell'Accademia Gioenia di Scienze Naturali di Catania, Ser. 7, 5: 63-95.

Massa B., Lo Cascio P., Ientile R., Canale E. \& La Mantia T., 2015. Gli uccelli delle isole circumsiciliane. Il Naturalista siciliano, 39: 105-373.

Masseti M., 1998. Holocene endemic and anthropochorous wild mammals of the Mediterranean islands. Anthropozoologica, 28: 3-20.

Masseti M., 2002. Inquadramento paleontologico, archeozoologico e paleobiogeografico. In: Corti C., Lo Cascio P., Masseti M. \& Pasta S. (Eds.), Storia naturale delle Isole Pelagie. L'Epos Società Editrice, Palermo: pp. 27-30.

Masseti M., 2003. Fauna toscana. Galliformi non migratori, Lagormorfi e Artiodattili. Agenzia Regionale per lo Sviluppo e l'Innovazione nel settore Agricolo-forestale (ARSIA)/Regione Toscana, Firenze.

Masseti M., 2008. Erinaceomorfi, Soricomorfi,Lagomorfi e Roditori endemici ed antropocori dell'Italia continentale ed insulare. In: Amori G., Contoli L. \& Nappi A. (Eds.), Fauna d'Italia. Mammalia II. Erinaceomorpha, Soricomorpha, Lagomorpha, Rodentia. vol. XLIV: 33-65. Edizioni Calderini de il Sole24 Ore, Milano: 33-65.

Masseti M., 2009a. The wild goats, Capra aegagrus 
Erxleben, 1777, of the Mediterranean Sea and the Eastern Atlantic Ocean islands. Mammal Review, 39: 141-157.

Masseti M., 2009b. Mammals of the Mediterranean islands: homogenisation and the loss of biodiversity. Mammalia, 73: 169-202.

Masseti M., 2010. Zoologia storica e archeologica dei Felidi italiani. In: Randi E., Ragni B., Bizzarrini L., Agostini N. \& Tedaldi G. (a cura di), Biologia e conservazione dei Felidi in Italia. Atti del convegno Santa Sfia (FC) 7-8 Novembre 2008. Ente Parco Nazionale Foreste Casentinesi: 9-28.

Masseti M., 2014. Las cabras selvajes, Capra aegagrus Erxleben, 1777, de las islas del Mediterraneo/The wild goats, Capra aegagrus Erxleben, 1777, of the Mediterranean islands. In: Seguí Campaner et al. (Eds.), Boc balear/Cuatro milenios de historia, diez años de Mallorca, Department de Medi Ambient, Palma de Mallorca: 94-107.

Masseti M., 2016. Zoologia della Sicilia araba e normanna (827-1194). Edizioni Danaus, Palermo, 344 pp.

Masseti M. \& De Marinis A.M., 2008. Prehistoric and Historic Artificial Dispersal of Lagomorphs on the Mediterranean islands. In: Alves P.C., Ferrand N. \& Hackländer K. (Eds.), Lagomorph Biology: Evolution, Ecology, and Conservation. Springer-Verlag, Berlin and Heidelberg: 13-24.

Masseti M. \& Rustioni M., 1990. Mammiferi italiani del tardo Pleistocene e dell'Olocene: la produzione artistica e i dati paleontologici. Studi per l'Ecologia del Quaternario, 12: 89-112.

Masseti M. \& Zava B., 2002. Nineteenth century wild ungulates (Mammalia, Artiodactyla) of the island of Lampedusa (Pelagian archipelago, Italy). Biogeographia, 22: 199-215.

Maurici F., 1999. Le Egadi dalla tarda antichità agli inizi dell'età moderna: storia e archeologia. La Fardelliana, Trapani.

Mo G., 2011. Mediterranean Monk Seal (Monachus monachus) Sightings in Italy (1998-2010) and Implications for Conservation. Aquatic Mammals, 37 : 236-240.

Pignatti S., 1982. Flora d'Italia. 3 voll. Edagricole, Bologna.

Pratesi F. \& Tassi F., 1974. Guida alla natura della Sicilia. Arnoldo Mondatori editore, Milano, 296 pp.

Premuda G. \& Mellone U., 2008. Presenza regolare del Falco della Regina, Falco eleonorae, sull'Isola di Marettimo (Egadi, Sicilia). Rivista Italiana di Ornitologia, 77: 147-148.

Racheli G., 1986. Egadi, mare e vita. Mursia, Milano, $348 \mathrm{pp}$.

Riggio S., 1976. Degradazione dell'ambiente ed estinzione della fauna vertebrata in Sicilia. Atti del I ${ }^{\circ}$ Con- vegno Siciliano di Ecologia. Società Editrice Delphinus, Noto: 67-93.

Rizzitano U. (Ed.), 1994. Idrisi. Il Libro di Ruggiero. Il diletto di chi è appassionato per le peregrinazioni attraverso il mondo. Flaccovio editore, Palermo.

Ruta C. (Ed.), 2007. La Sicilia nelle geografie arabe del medioevo. Edi.bi.si., Messina.

Sacchi O., Zava B., Ziliani U. \& Baratelli D., 1994. Osservazioni sul muflone (Ovis ammon musimon) nell'isola di Marettimo. Riassunti $1^{\circ}$ Convegno italiano di Teriologia. Pisa, 27-29 ottobre 1994. Università degli Sudi di Pisa/Università degli Studi di Siena: 151.

Sarà M., 1995. The Sicilian (Crocidura sicula) and the Canary (C. canariensis) shrew (Mammalia, Soricidae): peripheral isolate formation and geographic variation. Bollettino Zoologico, 62: 173-182.

Sarà M., 1996. A landmark based morphometric analysis of Crocidurinae: a case study on endemic shrews (C. sicula and C. canariensis: Soricidae, Mammalia). In: Marcus L.F., Corti M., Loy A., Slice D. \& Naylor G. (Eds.), Advanves in morphometrics. Nato Advances Syudy Institute, Plenum Press, New York: 335-344.

Sarà M., 1998. I mammiferi delle isole mediterranee. L'Epos Società Editrice, Palermo, 168+XVI pp.

Sarà M., 2008. Le ricerche sui Mammiferi in Sicilia. In Autori Vari: Atlante della biodiversità della Sicilia: vertebrati terrestri. Studi e Ricerche 6. Arpa Sicilia, Palermo: 21-24.

Sara' M. \& Casamento G., 1995. Morphometrics of the wood mouse (Apodemus sylvaticus, Mammalia, Rodentia) in the Mediterranean. Bollettino Zoologico, 62: $313-320$.

Sarà M. \& Vitturi R., 1996. Crocidura populations (Mammalia, Soricidae) from the Sicilian-Maltese insular area. Hystrix (n.s.), 8: 121-132.

Sarà M., Lo Valvo M. \& Zanca L., 1990. Insular variation in central Mediterranean Crocidura Wagler, 1832 (Mammalia, Soricidae). Bollettino Zoologico, 57: 283-293.

Sironi V. (a cura di), 2004. Quasi tutti gli abitanti praticano la caccia di passo. Itinerari. Isole siciliane. Eolie, Egadi, Pelagie, Pantelleria, Ustica. Touring Club Italiano, Milano: 94-95.

Smyth W.H., 1824. Memoir descriptive of the resources, inhabitants and hydrography of Sicily and its islands, interspersed with antiquarian and other notices. J. Murray, London.

Spagnesi M., 2002. Silvilago Sylvilagus floridanus (J.A. Allen, 1890). In: Spagnesi M. \& De Marinis A.M. (Eds.), Mammiferi d'Italia. Quaderni di Conservazione della Natura, 14, Mininestro dell'Ambiente, Istituto Nazionale per la Fauna Selvatica, Ozzano dell'Emilia (Bologna), pp. 156-157. 
Tusa S., di Maida G., Pastoors A., Piezonka H., G.-C. Weniger \& Terberger T., 2013. The Grotta di Cala dei Genovesi - new studies on the Ice Age cave art on Sicily. Praehistorische Zeitschrift, 88: 1-22.

Vaccaro V. (Ed.), 2016. Marèttimo. Nuova Guida per viaggiatori e curiosi. Storia, natura e itinerari dell'isola più lontana dell'arcipelago delle Egadi. Associazione Culturale, Sportiva, Ricreativa, Turistica "Marèttimo".

Vogel P., Hutterer R. \& Sarà M., 1989. The correct name, species diagnosis, and distribution of the $\mathrm{Si}$ - cilian shrew. Bonner zoologische Beiträge, 40: 243348.

Vogel P., Maddalena T. \& Schembri P., 1990. Cytotaxonomy of shrews of the genus Crocidura from Mediterranean islands. Vie et Milieu, 40: 124-129.

Zava B., 1992. Specie estinte ed introdotte. In: Nigris E. \& Trifirò F. (Eds.), Interventi per il risanamento della fascia costiera e per la riqualificazione del paesaggio delle Isole Egadi. Studi di base: componenti biotiche dell'Isola di Marettimo. Relazione tecnica inedita. Progetto MedSPA, Castalia/Italico/Onas, Palermo, pp. 233-242. 
